\title{
Penerapan Algoritma K-Means dan K-Medoids Clustering untuk Mengelompokkan Tindak Kriminalitas Berdasarkan Provinsi
}

\author{
Hotma Dame Tampubolon ${ }^{1 凶)}$, Suhada ${ }^{2)}$, M Safii ${ }^{3)}$, Solikhun ${ }^{4)}$, Dedi Suhendro ${ }^{5)}$ \\ 1) Program Studi Teknik Informatika, STIKOM Tunas Bangsa, Pematangsiantar, Indonesia \\ 1) hotmatampubolon26@gmail.com
}

\author{
${ }^{233) 45)}$ AMIK Tunas Bangsa, Pematangsiantar, Indonesia \\ 2) suhada.atbegmail.com \\ ${ }^{3)}$ m. safiidamiktunasbangsa.ac.id \\ 4) solikhun@amiktunasbangsa.ac.id \\ 5) dedi.sulamiktunasbangsa.ac.id
}

\begin{abstract}
Crime is a problem that often occurs in everyday life and everywhere, including in various provinces in Indonesia. With so many criminal acts in Indonesia, it is necessary to group crime-prone areas in Indonesia by province as an effort to determine whether an area requires extra supervision or not. In this study, criminal acts will be grouped using the K-Means and K-Medoids clustering algorithms. The data is processed into two clusters, namely the high crime rate cluster $(C 1)$ and the low crime rate cluster (C2). The results of the K-Means algorithm are obtained with $C 1$ having 6 members and $C 2$ having 28 members. While the results of the K-Medoids algorithm are obtained with $C 1$ having 7 members and $C 2$ having 27 members. The difference in the number of clusters on the performance of each algorithm has a different calculation pattern so that the superior performance of the algorithm depends on the data to be processed.
\end{abstract}

\section{Keywords-Crime, K-Means, K-Medoids, Clustering}

Intisari- Kriminalitas merupakan masalah yang sering terjadi di kehidupan sehari-hari dan dimana saja termasuk di berbagai provinsi yang ada di Indonesia. Dengan banyaknya tindak kriminalitas di Indonesia, diperlukan adanya pengelompokan daerah rawan tindak kriminalitas di Indonesia berdasarkan provinsi sebagai salah satu usaha untuk menentukan suatu daerah memerlukan pengawasan ekstra atau tidak. Pada penelitian ini akan dilakukan pengelompokkan tindak kriminalitas dengan menggunakan algoritma $\mathrm{K}$-Means dan $K$-Medoids clustering. Data diolah menjadi dua cluster yaitu cluster tingkat tindak kriminalitas tinggi (C1) dan cluster tingkat tindak kriminalitas rendah (C2). Hasil algoritma $K$ Means diperoleh dengan $\mathrm{C} 1$ memiliki 6 anggota dan $\mathrm{C} 2$ memiliki 28 anggota. Sedangkan hasil algoritma $K$-Medoids diperoleh dengan $\mathrm{C} 1$ memiliki 7 anggota dan C2 memiliki 27 anggota. Perbedaan jumlah klaster pada kinerja tiap algoritma memiliki pola perhitungan yang berbeda sehingga keunggulan kinerja algoritma tergantung pada data yang akan diproses.

Kata kunci - Kriminalitas, K-Means, K-Medoids, Clustering

\section{Pendahuluan}

Kriminalitas merupakan kejahatan, tindak kriminal, atau juga sebagai suatu tindakan yang bersifat negatif. Seringkali, tindakan ini akan merugikan banyak pihak dan pelaku tindakannya disebut sebagai seorang kriminal. Kriminalitas sering terjadi di berbagai Negara, termasuk di Indonesia. Sebagian besar jenis kriminal yang sering terjadi di Indonesia adalah kejahatan terhadap nyawa (pembunuhan), kejahatan terhadap fisik (penganiayaan), kejahatan terhadap kesusilaan (pemerkosaan/pencabulan), pencurian, narkoba, penipuan bahkan korupsi [1].

Dengan banyaknya tindak kriminalitas di Indonesia, diperlukan adanya pengelompokan daerah rawan tindak kriminalitas di Indonesia berdasarkan provinsi sebagai salah satu usaha untuk membantu pihak kepolisian dalam mengambil keputusan apakah suatu daerah memerlukan pengawasan ekstra atau tidak. Oleh karena itu, maka dibuatlah pengelolahan data yang dapat menyelesaikan permasalahan tersebut yaitu pengelompokan daerah rawan tindak kriminalitas di Indonesia menggunakan teknik data mining berupa analisis klaster (clustering). Di antara banyaknya analisis klaster yang ada terdapat dua jenis analisis klaster yang memiliki algoritma yang saling berkaitan, yaitu $K$-Means dan $K$-Medoids clustering [2].

Dalam penelitian yang dilakukan Rhamadani dan tim menggunakan metode K-Means dan K-Medoids untuk mengelompokkan nilai ujian nasional tingkat SMK menunjukkan bahwa pengelompokan data menggunakan algoritma $K$-Means dan $K$-Medoids memiliki pola perhitungan data yang berbeda, hasil pengelompokkan pada algoritma $K$-Means menghasilkan klaster baik sebanyak 14 anggota, klaster sedang 46 anggota dan klaster cukup 49 anggota. Lalu, pada algoritma $K$-Medoids diperoleh hasil klaster baik 27 anggota, klaster sedang 48 anggota dan klaster cukup 43 anggota [3]. 
Penelitian yang dilakukan oleh Anggoro dan tim menggunakan metode $K$-Means clustering, K-Medoids clustering dan metode Kernel Destiny untuk mengelompokkan daerah rawan pencurian kendaraan bermotor (curanmor) di kota semarang. Hasil pengujian yang didapat yaitu $K$-Means dan $K$-Medoids mempunyai hasil yang berbeda-beda. Sedangkan metode Kernel Density memiliki nilai verifikasi daerah rawan (tingkat kerawanan tinggi dan sedang) yang paling besar dibanding dengan metode K-Means dan K-Medoids, yaitu 82,35\% [4].

Pada penelitian ini data kriminalitas yang digunakan diambil dari Badan Pusat Statistik melalui situs https://www.bps.go.id/. Data yang didapatkan akan dilakukan penelitian dalam mengelompokkan tindak kriminalitas berdasarkan provinsi menggunakan algoritma $K$ Means dan K-Medoids. Pengelompokan dibagi menjadi 2 cluster yaitu cluster tindak kriminalitas tinggi dan cluster tindak kriminalitas rendah. Pengelompokan dilakukan untuk menjadi sebuah solusi agar memudahkan pihak kepolisian dalam mengambil keputusan apakah suatu daerah memerlukan pengawasan ekstra atau tidak.

\section{Metodologi Penelitian}

\section{A. Data Mining}

Data mining adalah proses penggalian informasi dari data set yang besar melalui penggunaan algoritma dan teknik yang diambil dari bidang statistik, machine learning dan database sistem manajemen [5].

Data mining merupakan inti dari proses Knowledge Discovery in Database (KDD). KDD dapat dikatakan sebagai penyelesaian masalah dengan menganalisa data yang ada pada database dengan data tersimpan secara elektronik dan pencariannya dilakukan otomatis seperti pada komputer [6].

\section{B. Algoritma K-Means}

$K$-Means merupakan salah satu algoritma Clustering yang masuk dalam kelompok Unsupersived Learning yang digunakan untuk membagi data menjadi beberapa kelompok dengan system partisi. Pada setiap cluster terdapat titik pusat (centroid) yang mempresentasikan cluster tersebut [7]. Prinsip utama dari algoritma $K$-Means ini adalah menyusun $\mathrm{k}$ buah partisi/pusat (centroid)/ rata-rata (mean) dari sekumpulan data.

Langkah-langkah algoritma K-Means [8] :

1. Tentukan jumlah Cluster (k) pada data set.

2. Tentukan titik pusat (Centroid) secara random.

3. Untuk menghitung jarak terdekat dengan centroid, dapat menggunakan rumus Euclidean Distance di bawah ini :

$$
\begin{aligned}
& d=\sqrt{\left(x_{i}-s_{i}\right)+\left(y_{i}-t_{i}\right)} \\
& \text { Keterangan : } \\
& \begin{array}{ll}
\mathrm{d} \quad=\text { Euclidean Distance } \\
\mathrm{i} \quad=\text { banyak objek } \\
\mathrm{x}, \mathrm{y} \quad=\text { Titik koordinat objek } \\
\mathrm{s}, \mathrm{t} \quad=\text { Titik koordinat centroid }
\end{array}
\end{aligned}
$$

4. Hitung pusat cluster yang baru dengan anggota cluster yang sekarang. Pusat cluster adalah rata-rata dalam sebuah cluster. Dapat dihitung mrnggunakan rumus:

$V_{i j}=\frac{1}{N} \sum_{k=0}^{N_{i}} X_{k j}$

Keterangan:

$\mathrm{V}_{\mathrm{ij}} \quad=$ Centeroid rata-rata cluster ke-i untuk variable ke-j

$\mathrm{N}_{\mathrm{i}} \quad$ = Jumlah anggota cluster ke-i

$\mathrm{i}, \mathrm{k}=$ Indeks dari cluster

$\mathrm{j} \quad=$ Indeks dari variable

$\mathrm{X}_{\mathrm{kj}}=$ Nilai data ke-k variable ke-j untuk cluster tersebut.

5. Lakukan kembali langkah ke-3 dan langkah ke-4 dan iterasi mencapai centroid bernilai optimal.

\section{Algoritma K-Medoids}

K-Medoids adalah salah satu metode partisi, karena menggunakan objek yang paling terpusat (medoids) di cluster menjadi pusat cluster dari nilai rata-rata objek dalam sebuah cluster [9].

Algoritma $\mathrm{K}$-Medoids adalah algoritma clustering yang mirip dengan $K$-Means. Perbedaan dari kedua algoritma ini yaitu algoritma $K$-Medoids menggunakan objek sebagai perwakilan (medoid) sebagai pusat cluster, sedangkan $K$ Means menggunakan nilai rata-rata (mean) sebagai pusat cluster. Langkah-langkah algoritma K-Medoids [10] :

1. Inisialisasi pusat cluster sebanyak $\mathrm{k}$ (jumlah cluster).

2. Alokasikan setiap data (objek) ke cluster terdekat menggunakan persamaan ukuran jarak Euclidian Distance dengan persamaan (1).

3. Pilih secara acak objek pada masing-masing cluster sebagai kandidat medoids baru.

4. Hitung jarak setiap objek yang berada pada masingmasing cluster dengan kandidat medoids baru.

5. Hitung total simpangan (S) dengan menghitung nilai total distance baru - total distance lama. Jika $\mathrm{S}<0$, maka tukar objek dengan data cluster untuk membentuk sekumpulan $\mathrm{k}$ objek baru sebagai medoid.

6. Ulangi langkah 3 sampai 5 hingga tidak terjadi perubahan medoids, sehingga didapatkan cluster beserta anggota cluster masing-masing.

\section{Pengujian RapidMiner}

Rapidminer adalah perangkat lunak yang dapat diakses siapa saja dan bersifat terbuka (open source). Rapidminer memiliki kurang lebih 500 operator data mining, termasuk operator untuk input, output, data preprocessing dan visualisasi [11]. Pada penelitian ini, Pengujian data menggunakan tools Rapidminer 5.3 bertujuan untuk mencocokkan kesesuaian hasil dari perhitungan manual algoritma $K$-Means dan algoritma $K$-Medoids.

\section{E. Tahapan Pengumpulan Data}

Sumber data penelitian yang digunakan pada penelitian ini diambil dari website resmi Badan Pusat Statistik atau https://www.bps.go.id/ yaitu tentang data kriminalitas menurut provinsi dari tahun 2017-2019 yang terdiri dari 34 
provinsi. Variabel yang digunakan ada 6 yaitu tindak kejahatan terhadap nyawa (pembunuhan), kejahatan terhadap fisik (penganiayaan), kejahatan terhadap kesusilaan (pemerkosaan/pencabulan), kejahatan terhadap hak milik/barang (pencurian), narkoba, dan korupsi. Data akan diolah dengan melakukan clustering tindak kriminalitas menurut provinsi dalam 2 cluster yaitu cluster tindak kriminalitas tinggi (C1) dan cluster tindak kriminalitas rendah $(\mathrm{C} 2)$.

\section{F. Data}

Data yang digunakan dalam penelitian ini adalah data sekunder yang diperoleh dari Badan Pusat Statistik (BPS) yaitu data tindak kriminalitas berdasarkan provinsi dari tahun 2017-2019 dengan jumlah data sebanyak 34 provinsi dengan kriteria tindak kejahatan terhadap nyawa, kejahatan terhadap fisik, kejahatan terhadap kesusilaan, kejahatan terhadap hak milik/barang, narkoba, serta penipuan dan korupsi. Berikut tabel data yang akan digunakan dengan nilai rata-rata (tahun 2017-2019) dari setiap kriteria:

TABEL 1. DATA TINDAK KRIMINALITAS BERDASARKAN PROVINSI

\begin{tabular}{|l|c|c|c|c|c|c|}
\hline \multirow{2}{*}{ Provinsi } & \multicolumn{5}{|c|}{ Tindak Kriminalitas } \\
\cline { 2 - 7 } & A & B & C & D & E & F \\
\hline Aceh & 25 & 1498 & 280 & 3063 & 1483 & 1310 \\
\hline Sumatera Utara & 101 & 5230 & 254 & 11389 & 6123 & 4960 \\
\hline Sumatera Barat & 15 & 2171 & 356 & 7382 & 735 & 1693 \\
\hline Riau & 26 & 854 & 104 & 2497 & 1520 & 1004 \\
\hline Kepulauan Riau & 7 & 601 & 128 & 1552 & 390 & 639 \\
\hline Jambi & 21 & 775 & 91 & 3203 & 519 & 1343 \\
\hline Sumatera selatan & 131 & 1835 & 188 & 4799 & 1797 & 2155 \\
\hline Kep. Bangka Belitung & 12 & 119 & 44 & 1014 & 310 & 164 \\
\hline Bengkulu & 29 & 406 & 90 & 1568 & 188 & 536 \\
\hline Lampung & 27 & 446 & 178 & 2982 & 2009 & 1292 \\
\hline DKI Jakarta & 62 & 1777 & 144 & 4872 & 7422 & 5603 \\
\hline Banten & 16 & 337 & 126 & 1603 & 437 & 550 \\
\hline Jawa Barat & 52 & 2002 & 445 & 6749 & 1236 & 4026 \\
\hline Jawa Tengah & 33 & 661 & 241 & 4422 & 1216 & 1443 \\
\hline DI Yogyakarta & 12 & 384 & 45 & 1828 & 274 & 924 \\
\hline Jawa timur & 66 & 2363 & 259 & 7473 & 3252 & 3984 \\
\hline Bali & 9 & 579 & 86 & 1296 & 729 & 440 \\
\hline Nusa Tenggara Barat & 5 & 439 & 47 & 2096 & 236 & 662 \\
\hline Nusa Tenggara Timur & 47 & 2422 & 220 & 2115 & 66 & 774 \\
\hline Kalimantan Barat & 20 & 223 & 163 & 2222 & 644 & 577 \\
\hline Kalimantan Tengah & 24 & 225 & 79 & 874 & 587 & 256 \\
\hline Kalimantan Selatan & 35 & 371 & 57 & 3367 & 1529 & 450 \\
\hline Kalimantan Timur & 17 & 658 & 117 & 1994 & 2238 & 639 \\
\hline Kalimantan Utara & 13 & 77 & 40 & 520 & 404 & 298 \\
\hline Sulawesi Utara & 74 & 3456 & 307 & 1908 & 381 & 1296 \\
\hline Gorontalo & 14 & 1351 & 177 & 887 & 58 & 475 \\
\hline Sulawesi Tengah & 15 & 1672 & 220 & 4665 & 296 & 1182 \\
\hline Sulawesi Barat & 13 & 1099 & 56 & 811 & 299 & 292 \\
\hline Sulawesi Selatan & 62 & 2817 & 222 & 6417 & 1015 & 3435 \\
\hline Sulawesi Tenggara & 12 & 691 & 109 & 622 & 64 & 161 \\
\hline Maluku & 11 & 793 & 141 & 857 & 103 & 316 \\
\hline Maluku Utara & 11 & 189 & 122 & 123 & 79 & 47 \\
\hline Papua Barat & 10 & 608 & 247 & 1317 & 56 & 361 \\
\hline Papua & 44 & 1248 & 96 & 4135 & 32 & 561 \\
\hline
\end{tabular}

Keterangan:

$\mathrm{A}=$ Kejahatan terhadap nyawa

$\mathrm{B}=$ Kejahatan terhadap fisik

$\mathrm{C}=$ Kejahatan terhadap kesusilaan

$\mathrm{D}=$ Kejahatan terhadap hak milik/barang
$\mathrm{E}=$ Narkoba

$\mathrm{F}=$ Penipuan dan korupsi

\section{HASIL DAN PEMBAHASAN}

\section{A. Perhitungan Hasil Algoritma K-Means}

1. Jumlah cluster yang digunakan adalah 2 cluster, yaitu cluster tingkat tindak kriminalitas tinggi (C1) dan cluster tingkat tindak kriminalitas rendah (C2).

2. Titik Centroid atau pusat cluster dipilih secara acak dari dataset. Pusat cluster tersebut dapat diketahui pada tabel 2 berikut:

TABEL 2. CENTROID DATA AWAL

\begin{tabular}{|l|c|c|c|c|c|c|}
\hline Cluster & A & B & C & D & E & F \\
\hline Sumatera Utara (C1) & 101 & 5230 & 254 & 11389 & 6123 & 4960 \\
\hline Maluku Utara (C2) & 11 & 189 & 122 & 123 & 79 & 47 \\
\hline
\end{tabular}

3. Menghitung jarak setiap data terhadap centeroid (Pusat Cluster) menggunakan rumus Euclidean Distance pada persamaan 1 algoritma K-Means, seperti berikut ini:

$\operatorname{Data}_{(1,1)}$

$=\sqrt{\begin{array}{c}(25-101)^{2}+(1498-5230)^{2}+(280-254)^{2}+ \\ \left(3063-11389^{2}+(1483-6123)^{2}+(1310-4960)^{2}\right.\end{array}}$

$=10867,78$

$\operatorname{Data}_{(2,1)}$

$=\sqrt{\begin{array}{l}(25-11)^{2}+(1498-189)^{2}+(280-122)^{2}+ \\ (3063-123)^{2}+(1483-79)^{2}+(1310-47)^{2}\end{array}}$

$=3734,78$

$\operatorname{Data}_{(1,34)}$

$=\sqrt{\begin{array}{c}(44-101)^{2}+(1248-5230)^{2}+(96-254)^{2}+ \\ \left(4135-11389^{2}+(32-6123)^{2}+(561-4960)^{2}\right.\end{array}}$

$=11178,39$

$\mathrm{D}_{(2,34)}$

$=\sqrt{\begin{array}{c}(44-11)^{2}+(1248-189)^{2}+(96-122)^{2}+ \\ (4135-123)^{2}+(32-79)^{2}+(561-47)^{2}\end{array}}$

$=4181,60$

Hasil perhitungan jarak data dengan titik pusat cluster pada iterasi 1 menggunakan Euclidean distance dapat dilihat pada tabel 3 berikut:

TABel 3. Hasil Perhitungan Jarak Pusat Cluster ITERASI 1

\begin{tabular}{|l|c|c|c|}
\hline \multirow{2}{*}{ Provinsi } & \multicolumn{2}{c|}{ Jarak ke Centroid } & \multirow{2}{*}{ Jarak } \\
\cline { 2 - 3 } & Cluster 1 & Cluster 2 & Terdekat \\
\hline Aceh & 10867,78 & 3734,78 & $\mathrm{C} 2$ \\
\hline Sumatera Utara & 0 & 14595,46 & $\mathrm{C} 1$ \\
\hline Sumatera Barat & 8070,63 & 7734,06 & $\mathrm{C} 2$ \\
\hline Riau & 11622,50 & 3011,80 & $\mathrm{C} 2$ \\
\hline Kepulauan Riau & 13029,09 & 1630,65 & $\mathrm{C} 2$ \\
\hline
\end{tabular}




\begin{tabular}{|l|c|c|c|}
\hline Jambi & 11462,02 & 3421,12 & $\mathrm{C} 2$ \\
\hline Sumatera selatan & 9030,04 & 5655,81 & $\mathrm{C} 2$ \\
\hline Kep. Bangka Belitung & 13806,06 & 933,76 & $\mathrm{C} 2$ \\
\hline Bengkulu & 13211,77 & 1545,14 & $\mathrm{C} 2$ \\
\hline Lampung & 11133,49 & 3676,71 & $\mathrm{C} 2$ \\
\hline DKI Jakarta & 7517,24 & 10481,72 & $\mathrm{C} 1$ \\
\hline Banten & 13096,16 & 1610,44 & $\mathrm{C} 2$ \\
\hline Jawa Barat & 7532,83 & 8029,19 & $\mathrm{C} 1$ \\
\hline Jawa Tengah & 10289,19 & 4686,19 & $\mathrm{C} 2$ \\
\hline DI Yogyakarta & 12862,66 & 1938,59 & $\mathrm{C} 2$ \\
\hline Jawa timur & 5722,86 & 9183,59 & $\mathrm{C} 1$ \\
\hline Bali & 13155,33 & 1451,30 & $\mathrm{C} 2$ \\
\hline Nusa Tenggara Barat & 12747,35 & 2088,96 & $\mathrm{C} 2$ \\
\hline Nusa Tenggara Timur & 12169,87 & 3081,22 & $\mathrm{C} 2$ \\
\hline Kalimantan Barat & 12583,67 & 2238,04 & $\mathrm{C} 2$ \\
\hline Kalimantan Tengah & 13726,86 & 932,23 & $\mathrm{C} 2$ \\
\hline Kalimantan Selatan & 11377,63 & 3581,39 & $\mathrm{C} 2$ \\
\hline Kalimantan Timur & 11956,55 & 2955,06 & $\mathrm{C} 2$ \\
\hline Kalimantan Utara & 14113,23 & 587,79 & $\mathrm{C} 2$ \\
\hline Sulawesi Utara & 11808,27 & 3943,21 & $\mathrm{C} 2$ \\
\hline Gorontalo & 13500,05 & 1456,22 & $\mathrm{C} 2$ \\
\hline Sulawesi Tengah & 10300,84 & 4916,70 & $\mathrm{C} 2$ \\
\hline Sulawesi Barat & 13591,004 & 1189,21 & $\mathrm{C} 2$ \\
\hline Sulawesi Selatan & 7678,74 & 7673,85 & $\mathrm{C} 2$ \\
\hline Sulawesi Tenggara & 14010,76 & 717,21 & $\mathrm{C} 2$ \\
\hline Maluku Utara & 14595,46 & 0 & $\mathrm{C} 2$ \\
\hline Papua Barat & 13445,28 & 1309,94 & $\mathrm{C} 2$ \\
\hline Papua & 11178,39 & 4181,60 & $\mathrm{C} 2$ \\
\hline
\end{tabular}

4. Menentukan centroid baru untuk iterasi selanjutnya dengan menghitung nilai rata-rata (mean) pada masing-masing cluster. Berikut adalah nilai centroid baru untuk iterasi 2:

TABel 4. CENTROID Data BarU

\begin{tabular}{|c|c|c|c|c|c|l|}
\hline Cluster & A & B & C & \multicolumn{1}{|c|}{ D } & E & F \\
\hline C 1 & 70,25 & 2843 & 275,5 & 7620,75 & 4508,25 & 4643,25 \\
\hline C 2 & 26,33 & 966,83 & 145,9 & 2404,63 & 656,46 & 842,5 \\
\hline
\end{tabular}

5. Ulangi langkah 3-4 hingga posisi data sudah tidak mengalami perubahan. Dalam penelitian ini iterasi dilakukan sampai iterasi ke 3. Hasil akhir posisi cluster pada centroid iterasi ke 3 dapat dilihat pada tabel dibawah ini:

Tabel 5. Pembagian Cluster Pada Iterasi 3

\begin{tabular}{|l|c|}
\hline \multicolumn{1}{|c|}{ Provinsi } & Letak Cluster \\
\hline Aceh & $\mathrm{C} 2$ \\
\hline Sumatera Utara & $\mathrm{C} 1$ \\
\hline Sumatera Barat & $\mathrm{C} 1$ \\
\hline Riau & $\mathrm{C} 2$ \\
\hline Kepulauan Riau & $\mathrm{C} 2$ \\
\hline Jambi & $\mathrm{C} 2$ \\
\hline Sumatera selatan & $\mathrm{C} 2$ \\
\hline Kep. Bangka Belitung & $\mathrm{C} 2$ \\
\hline Bengkulu & $\mathrm{C} 2$ \\
\hline Lampung & $\mathrm{C} 2$ \\
\hline DKI Jakarta & $\mathrm{C} 1$ \\
\hline Banten & $\mathrm{C} 2$ \\
\hline Jawa Barat & $\mathrm{C} 1$ \\
\hline Jawa Tengah & $\mathrm{C} 2$ \\
\hline DI Yogyakarta & $\mathrm{C} 2$ \\
\hline Jawa timur & $\mathrm{C} 1$ \\
\hline Bali & $\mathrm{C} 2$ \\
\hline Nusa Tenggara Barat & $\mathrm{C} 2$ \\
\hline Nusa Tenggara Timur & $\mathrm{C} 2$ \\
\hline
\end{tabular}

\begin{tabular}{|l|l|}
\hline Kalimantan Tengah & C2 \\
\hline Kalimantan Selatan & $\mathrm{C} 2$ \\
\hline Kalimantan Timur & $\mathrm{C} 2$ \\
\hline Kalimantan Utara & $\mathrm{C} 2$ \\
\hline Sulawesi Utara & $\mathrm{C} 2$ \\
\hline Gorontalo & $\mathrm{C} 2$ \\
\hline Sulawesi Tengah & $\mathrm{C} 2$ \\
\hline Sulawesi Barat & $\mathrm{C} 2$ \\
\hline Sulawesi Selatan & $\mathrm{C} 1$ \\
\hline Sulawesi Tenggara & $\mathrm{C} 2$ \\
\hline Maluku & $\mathrm{C} 2$ \\
\hline Maluku Utara & $\mathrm{C} 2$ \\
\hline Papua Barat & $\mathrm{C} 2$ \\
\hline Papua & $\mathrm{C} 2$ \\
\hline
\end{tabular}

Pada Tabel 5 dijelaskan provinsi apa saja yang termasuk kategori tindak kriminalitas tinggi dan tindak kriminalitas rendah. Kategori tindak kriminalitas tinggi memiliki 6 anggota (Sumatera Utara, Sumatera Barat, DKI Jakarta, Jawa Barat, Jawa Timur, dan Sulawesi Selatan) dan tindak kriminalitas rendah memiliki 28 anggota (Aceh, Riau, Kepulauan Riau, Jambi, Sumatera Selatan, Kep.Bangka Belitung, Bengkulu, Lampung, Banten, Jawa Tengah, DI Yogyakarta, Bali, Nusa Tenggara Barat, Nusa Tenggara Timur, Kalimantan Barat, Kalimantan Tengah, Kalimantan Selatan, Kalimantan Timur, Kalimantan Utara, Sulawesi Utara, Gorontalo, Sulawesi Tengah, Sulawesi Barat, Sulawesi Tenggara, Maluku, Maluku Utara, Papua Barat, dan Papua).

\section{B. Perhitungan Hasil Algoritma K-Medoids}

Tahap selanjutnya menerapkan dataset menggunakan algoritma K-Medoids. Tahapan penerapan algoritma $K$ Medoids hampir sama dengan tahapan pada algoritma $K$ Means yang membedakan hanya pada pemilihan titik centroid yang digunakan. K-Medoids melakukan pemilihan titik centroid baru secara acak pada perhitungan jarak ke-2, sedangkan K-Means mengambil nilai mean pada jarak terkecil untuk dijadikan titik centroid di perhitungan jarak iterasi selanjutnya. Berikut adalah perhitungan algoritma $K$ Medoids:

1. Inisialisasi pusat cluster sebanyak 2 cluster dari data sampel. Untuk pemilihan setiap centroid dipilih secara acak. Seperti pada tabel 6 .

TABEL 6. MEDOID AWAL

\begin{tabular}{|l|c|c|c|c|c|c|}
\hline \multicolumn{1}{|c|}{ Cluster } & A & B & C & D & E & F \\
\hline Sumatera Utara (C1) & 101 & 5230 & 254 & 11389 & 6123 & 4960 \\
\hline Riau (C2) & 26 & 854 & 104 & 2497 & 1520 & 1004 \\
\hline
\end{tabular}

2. Menghitung nilai jarak dengan persamaan Euclidean Distance yang ditunjukkan oleh persaamaan 1 pada algoritma $K$-Means.

Berikut tabel hasil perhitungan jarak pada iterasi 1 algoritma K-Medoids: 
Vol. 2, No. 2, Nov 2021, pp. 6-12

Tabel 7. Hasil Perhitungan Algoritma K-Medoids ITERASI KE-1

\begin{tabular}{|l|c|c|c|c|}
\hline \multicolumn{1}{|c|}{ Provinsi } & C1 & C2 & $\begin{array}{c}\text { Jarak } \\
\text { Terpendek }\end{array}$ & $\begin{array}{c}\text { Cluster } \\
\text { yang } \\
\text { diikuti }\end{array}$ \\
\hline Aceh & & & & C2 \\
\hline Sumatera Utara & 0 & 11622,50 & 0 & $\mathrm{C} 1$ \\
\hline Sumatera Barat & 8070,63 & 5172,26 & 5172,26 & $\mathrm{C} 2$ \\
\hline Riau & 11622,50 & 0 & 0 & $\mathrm{C} 2$ \\
\hline Kepulauan Riau & 13029,09 & 1538,86 & 1538,86 & $\mathrm{C} 2$ \\
\hline Jambi & 11462,02 & 1273,49 & 1273,49 & $\mathrm{C} 2$ \\
\hline Sumatera selatan & 9030,04 & 2771,49 & 2771,49 & $\mathrm{C} 2$ \\
\hline $\begin{array}{l}\text { Kep. Bangka } \\
\text { Belitung }\end{array}$ & 13806,06 & 2216,53 & 2216,53 & $\mathrm{C} 2$ \\
\hline Bengkulu & 13211,77 & 1748,48 & 1748,48 & $\mathrm{C} 2$ \\
\hline Lampung & 11133,49 & 853,95 & 853,95 & $\mathrm{C} 2$ \\
\hline DKI Jakarta & 7517,24 & 7904,41 & 7517,24 & $\mathrm{C} 1$ \\
\hline Banten & 13096,16 & 1564,00 & 1564,00 & $\mathrm{C} 2$ \\
\hline Jawa Barat & 7532,83 & 5359,80 & 5359,80 & $\mathrm{C} 2$ \\
\hline Jawa Tengah & 10289,19 & 2011,67 & 2011,67 & $\mathrm{C} 2$ \\
\hline DI Yogyakarta & 12862,66 & 1493,67 & 1493,67 & $\mathrm{C} 2$ \\
\hline Jawa timur & 5722,86 & 6240,47 & 5722,86 & $\mathrm{C} 1$ \\
\hline Bali & 13155,33 & 1569,20 & 1569,20 & $\mathrm{C} 2$ \\
\hline $\begin{array}{l}\text { Nusa Tenggara } \\
\text { Barat }\end{array}$ & 12747,35 & 1449,94 & 1449,94 & $\mathrm{C} 2$ \\
\hline $\begin{array}{l}\text { Nusa Tenggara } \\
\text { Timur }\end{array}$ & 12169,87 & 2187,56 & 2187,56 & $\mathrm{C} 2$ \\
\hline Kalimantan Barat & 12583,67 & 1194,57 & 1194,57 & $\mathrm{C} 2$ \\
\hline Kalimantan Tengah & 13726,86 & 2111,96 & 2111,96 & $\mathrm{C} 2$ \\
\hline Kalimantan Selatan & 11377,63 & 1139,94 & 1139,94 & $\mathrm{C} 2$ \\
\hline Kalimantan Timur & 11956,55 & 969,75 & 969,75 & $\mathrm{C} 2$ \\
\hline Kalimantan Utara & 14113,23 & 2502,08 & 2502,08 & $\mathrm{C} 2$ \\
\hline Sulawesi Utara & 11808,27 & 2922,91 & 2922,91 & $\mathrm{C} 2$ \\
\hline Gorontalo & 13500,05 & 2293,87 & 2293,87 & $\mathrm{C} 2$ \\
\hline Sulawesi Tengah & 10300,84 & 2629,21 & 2629,21 & $\mathrm{C} 2$ \\
\hline Sulawesi Barat & 13591,00 & 2214,24 & 2214,24 & $\mathrm{C} 2$ \\
\hline Sulawesi Selatan & 7678,74 & 5039,81 & 5039,81 & $\mathrm{C} 2$ \\
\hline Sulawesi Tenggara & 14010,76 & 2524,48 & 2524,48 & $\mathrm{C} 2$ \\
\hline Maluku & 13727,27 & 2275,11 & 2275,11 & $\mathrm{C} 2$ \\
\hline Papua Barat & 2007,57 & 2007,57 & $\mathrm{C} 2$ \\
\hline Papua & 2291,08 & 2291,08 & $\mathrm{C} 2$ \\
\hline & & 80507,46 & \\
\hline
\end{tabular}

3. Setelah didapatkan hasil jarak dari setiap objek pada iterasi 1 maka lanjut ke iterasi 2. Kandidat centroid baru pada iterasi 2 dapat dilihat pada tabel 8 berikut:

TABEL 8. KANDIDAT CENTROID BARU

\begin{tabular}{|l|c|c|c|c|c|c|}
\hline \multicolumn{1}{|c|}{ Cluster } & A & B & C & D & E & F \\
\hline Sulawesi Selatan (C1) & 62 & 2817 & 222 & 6417 & 1015 & 3435 \\
\hline Lampung (C2) & 27 & 446 & 178 & 2982 & 2009 & 1292 \\
\hline
\end{tabular}

Hasil perhitungan jarak titik centroid baru terhadap keseluruhan data proses seperti pada Tabel 9.

TABel 9. Hasil Perhitungan JaraK Ke SETIAP NON MEDOIDS BARU

\begin{tabular}{|l|c|c|c|c|}
\hline \multicolumn{1}{|c|}{ Provinsi } & C1 & C2 & $\begin{array}{c}\text { Jarak } \\
\text { Terpendek }\end{array}$ & $\begin{array}{c}\text { Cluster } \\
\text { yang } \\
\text { diikuti }\end{array}$ \\
\hline Aceh & 4210,51 & 1183,50 & 1183,50 & $\mathrm{C} 2$ \\
\hline Sumatera Utara & 7678,74 & 11133,49 & 7678,74 & $\mathrm{C} 1$ \\
\hline Sumatera Barat & 2116,99 & 4914,40 & 2116,99 & $\mathrm{C} 1$ \\
\hline Riau & 5039,81 & 853,95 & 853,95 & $\mathrm{C} 2$ \\
\hline Kepulauan Riau & 6066,21 & 2262,60 & 2262,60 & $\mathrm{C} 2$ \\
\hline Jambi & 4375,02 & 1545,11 & 1545,11 & $\mathrm{C} 2$ \\
\hline Sumatera selatan & 2416,21 & 2455,89 & 2416,21 & $\mathrm{C} 1$ \\
\hline
\end{tabular}

\begin{tabular}{|c|c|c|c|c|}
\hline $\begin{array}{l}\text { Kep. Bangka } \\
\text { Belitung }\end{array}$ & 6906,68 & 2856,06 & 2856,06 & $\mathrm{C} 2$ \\
\hline Bengkulu & 6199,38 & 2428,23 & 2428,23 & $\mathrm{C} 2$ \\
\hline Lampung & 4796,30 & 0 & 0 & $\mathrm{C} 2$ \\
\hline DKI Jakarta & 7016,02 & 7295,98 & 7016,02 & $\mathrm{C} 1$ \\
\hline Banten & 6163,89 & 2222,18 & 2222,18 & $\mathrm{C} 2$ \\
\hline Jawa Barat & 1105,62 & 4975,50 & 1105,62 & $\mathrm{C} 1$ \\
\hline Jawa Tengah & 3555,00 & 1665,97 & 1665,97 & $\mathrm{C} 2$ \\
\hline DI Yogyakarta & 5819,48 & 2121,11 & 2121,11 & $\mathrm{C} 2$ \\
\hline Jawa timur & 2574,53 & 5713,48 & 2574,53 & $\mathrm{C} 1$ \\
\hline Bali & 6348,73 & 2287,65 & 2287,65 & $\mathrm{C} 2$ \\
\hline $\begin{array}{l}\text { Nusa Tenggara } \\
\text { Barat }\end{array}$ & 5714,55 & 2084,01 & 2084,01 & $\mathrm{C} 2$ \\
\hline $\begin{array}{l}\text { Nusa Tenggara } \\
\text { Timur }\end{array}$ & 5161,87 & 2949,91 & 2949,91 & $\mathrm{C} 2$ \\
\hline Kalimantan Barat & 5712,95 & 1732,64 & 1732,64 & $\mathrm{C} 2$ \\
\hline Kalimantan Tengah & 6910,45 & 2756,39 & 2756,39 & $\mathrm{C} 2$ \\
\hline Kalimantan Selatan & 4948,51 & 1052,57 & 1052,57 & $\mathrm{C} 2$ \\
\hline Kalimantan Timur & 5792,28 & 1226,27 & 1226,27 & $\mathrm{C} 2$ \\
\hline Kalimantan Utara & 7247,88 & 3127,44 & 3127,44 & $\mathrm{C} 2$ \\
\hline Sulawesi Utara & 5071,88 & 3589,26 & 3589,26 & $\mathrm{C} 2$ \\
\hline Gorontalo & 6512,43 & 3111,60 & 3111,60 & $\mathrm{C} 2$ \\
\hline Sulawesi Tengah & 3158,43 & 2698,87 & 2698,87 & $\mathrm{C} 2$ \\
\hline Sulawesi Barat & 6693,26 & 3013,10 & 3013,10 & $\mathrm{C} 2$ \\
\hline Sulawesi Selatan & 0 & 4796,30 & 0 & $\mathrm{C} 1$ \\
\hline Sulawesi Tenggara & 7052,70 & 3270,59 & 3270,59 & $\mathrm{C} 2$ \\
\hline Maluku & 6751,24 & 3036,95 & 3036,95 & $\mathrm{C} 2$ \\
\hline Maluku Utara & 7673,85 & 3676,71 & 3676,71 & $\mathrm{C} 2$ \\
\hline Papua Barat & 6423,56 & 2735,77 & 2735,77 & $\mathrm{C} 2$ \\
\hline Papua & 4112,37 & 2534,26 & 2534,26 & $\mathrm{C} 2$ \\
\hline \multicolumn{3}{|c|}{ Total Cost (Total Jarak Terpendek) } & 84930,98 & \\
\hline
\end{tabular}

4. Kemudian dilakukan perhitungan total simpangan (S) yang dihitung dari hasil perhitungan total cost (jarak terpendek) iterasi ke-1 dan ke-2. Dihitung dengan menggunakan perhitungan simpangan $\mathrm{S}$ dari jarak keduanya.

$\mathrm{S}=$ total cost baru - total cost lama

Dengan: Total jarak iterasi ke- $1=80507,46$ Total jarak iterasi ke- $2=84930,98$

Total simpangan $(\mathrm{S})=84930,98-80507,46$ $=4423,52$

5. Karena nilai $\mathrm{S}>0$ maka proses pengklasteran dihentikan. Berikut hasil akhir dari pembagian anggota tiap klaster menggunakan algoritm $K$ Medoids dapat dilihat pada Tabel 10.

TABel 10. Pembagian Cluster Pada Iterasi 2

\begin{tabular}{|l|c|}
\hline \multicolumn{1}{|c|}{ Provinsi } & Letak Cluster \\
\hline Aceh & $\mathrm{C} 2$ \\
\hline Sumatera Utara & $\mathrm{C} 1$ \\
\hline Sumatera Barat & $\mathrm{C} 1$ \\
\hline Riau & $\mathrm{C} 2$ \\
\hline Kepulauan Riau & $\mathrm{C} 2$ \\
\hline Jambi & $\mathrm{C} 2$ \\
\hline Sumatera selatan & $\mathrm{C} 1$ \\
\hline Kep. Bangka Belitung & $\mathrm{C} 2$ \\
\hline Bengkulu & $\mathrm{C} 2$ \\
\hline Lampung & $\mathrm{C} 2$ \\
\hline DKI Jakarta & $\mathrm{C} 1$ \\
\hline Banten & $\mathrm{C} 2$ \\
\hline Jawa Barat & $\mathrm{C} 1$ \\
\hline Jawa Tengah & $\mathrm{C} 2$ \\
\hline DI Yogyakarta & $\mathrm{C} 2$ \\
\hline Jawa timur & $\mathrm{C} 1$ \\
\hline Bali & $\mathrm{C} 2$ \\
\hline
\end{tabular}




\begin{tabular}{|l|l|}
\hline Nusa Tenggara Barat & C2 \\
\hline Nusa Tenggara Timur & C2 \\
\hline Kalimantan Barat & C2 \\
\hline Kalimantan Tengah & C2 \\
\hline Kalimantan Selatan & $\mathrm{C} 2$ \\
\hline Kalimantan Timur & $\mathrm{C} 2$ \\
\hline Kalimantan Utara & $\mathrm{C} 2$ \\
\hline Sulawesi Utara & $\mathrm{C} 2$ \\
\hline Gorontalo & $\mathrm{C} 2$ \\
\hline Sulawesi Tengah & $\mathrm{C} 2$ \\
\hline Sulawesi Barat & $\mathrm{C} 2$ \\
\hline Sulawesi Selatan & $\mathrm{C} 1$ \\
\hline Sulawesi Tenggara & $\mathrm{C} 2$ \\
\hline Maluku & $\mathrm{C} 2$ \\
\hline Maluku Utara & $\mathrm{C} 2$ \\
\hline Papua Barat & $\mathrm{C} 2$ \\
\hline Papua & $\mathrm{C} 2$ \\
\hline
\end{tabular}

Pada Tabel 10 dijelaskan provinsi apa saja yang termasuk kategori tindak kriminalitas tinggi dan tindak kriminalitas rendah. Kategori tindak kriminalitas tinggi memiliki 7 anggota (Sumatera Utara, Sumatera Barat, Sumatera Selatan, DKI Jakarta, Jawa Barat, Jawa Timur, dan Sulawesi Selatan) dan tindak kriminalitas rendah memiliki 27 anggota (Aceh, Riau, Kepulauan Riau, Jambi, Kep.Bangka Belitung, Bengkulu, Lampung, Banten, Jawa Tengah, DI Yogyakarta, Bali, Nusa Tenggara Barat, Nusa Tenggara Timur, Kalimantan Barat, Kalimantan Tengah, Kalimantan Selatan, Kalimantan Timur, Kalimantan Utara, Sulawesi Utara, Gorontalo, Sulawesi Tengah, Sulawesi Barat, Sulawesi Tenggara, Maluku, Maluku Utara, Papua Barat, dan Papua).

\section{Pengujian Menggunakan RapidMiner}

- Pada pengujian menggunakan Rapidminer algoritma K-Means menjelaskan bahwa hasil pengujian sesuai dengan perhitungan seperti pada gambar 1.

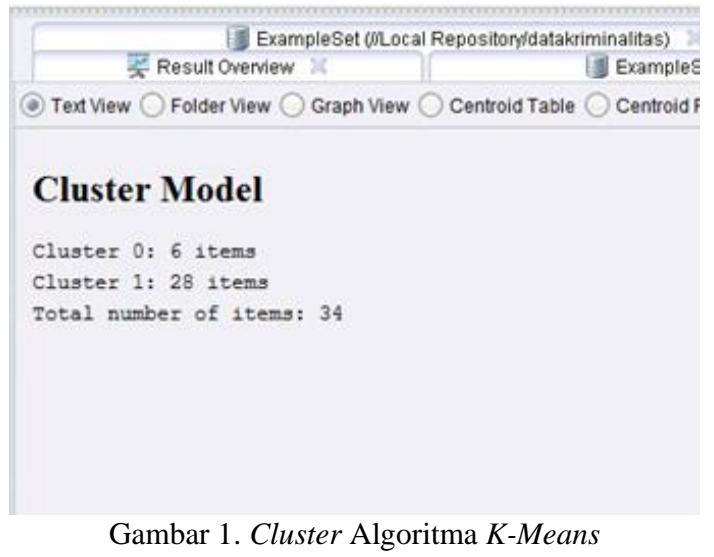

Gambar 1 menjelaskan bahwa cluster 0 memiliki 6 anggota yang merupakan kategori tindak kriminalitas tinggi dan cluster 1 memiliki 28 anggota termasuk kedalam kategori tindak kriminalitas rendah dari hasil pengujian menggunakan algoritma $K$-Means.

- Pada pengujian menggunakan Rapidminer algoritma K-Medoids menjelaskan bahwa hasil pengujian sesuai dengan perhitungan seperti pada Gambar 2.

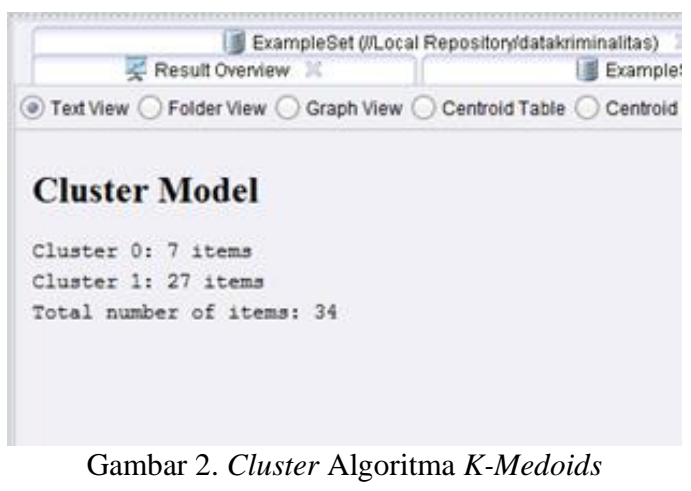

Gambar 2 menjelaskan bahwa cluster 0 memiliki 7 anggota yang merupakan kategori tindak kriminalitas tinggi dan cluster 1 memiliki 27 anggota termasuk kedalam kategori tindak kriminalitas rendah dari hasil pengujian menggunakan algoritma K-Means.

\section{KESIMPULAN}

Dari penilitian ini, dapat disimpulkan bahwa:

- Hasil algoritma K-Means diperoleh hasil cluster 1 dengan kategori tindak kriminalitas tinggi memiliki 6 anggota, cluster 2 dengan kategori tindak kriminalitas rendah memiliki 28 anggota. Sedangkan hasil perhitungan manual algoritma $K$ Medoids diperoleh hasil cluster 1 dengan kategori tindak kriminalitas tinggi memiliki 7 anggota, cluster 2 dengan kategori tindak kriminalitas rendah memiliki 27 anggota.

- Pengujian data pada masing-masing algoritma terhadap tools menghasilkan kesesuaian jumlah cluster yang sama antara hasil perhitungan manual algoritma K-Means dengan Rapidminer dan algoritma $K$-Medoids dengan Rapidminer.

- Pengelompokan data menggunakan algoritma $K$ means dan $K$-medoids memiliki sistem perhitungan data yang berbeda. Sehingga keunggulan kinerja algoritma tergantung pada data yang akan diproses.

\section{UCAPAN TERIMA KASIH}

Terima kasih kepada program studi Teknik Informatika, STIKOM Tunas Bangsa, Pematangsiantaratas dukungan dalam terlaksananya penelitian ini serta pembimbing yaitu Bapak Suhada dan Bapak M. Safii.

\section{REFERENSI}

[1] A. Supratman, "Menyoal Sikap Kejahatan Di Indonesia Di Era Industri 4.0 (Suatu Perspektif Kriminologi)," Leg. J. Perundang Undangan dan Huk. Pidana Islam, vol. 0, pp. 2742, 2020.

[2] Y. H. Susanti and E. Widodo, "Perbandingan K-Means dan KMedoids Clustering terhadap Kelayakan Puskesmas di DIY Tahun 2015," Pros. SI MaNIs (Seminar Nas. Integr. Mat. dan Nilai Islam., vol. 1, no. 1, pp. 116-122, 2017.

[3] N. N. Rhamadani, A. Fauzi, E. Nurlaelasari, and A. R. Pratama, "Implementasi algoritma k-means dan k-medoids dalam pengelompokan nilai ujian nasional tingkat smk," Conf. Innov. 
Appl. Sci. Technol. (CIASTECH 2020), no. Ciastech, pp. 717726, 2020.

[4] J. W. Anggoro, M. Awaluddin, and A. L. Nugraha, "Zonasi Daerah Rawan Pencurian Kendaraan Bermotor (Curamor) di Kota Semarang Dengan Menggunakan Metode Cluster Analysis," Geod. Undip, vol. 8, pp. 225-234, 2019.

[5] U. T. Suryadi and Y. Supriatna, "Sistem Clustering Tindak Kejahatan Pencurian Di Wilayah Jawa Barat Menggunakan Algoritma K-Means," J. Teknol. dan Komun. STMIK Subang, vol. 12, no. 1, pp. 15-27, 2019, doi: 10.47561/a.v12i1.147.

[6] R. T. Vulandari, "Pengelompokan Tingkat Keamanan Wilayah Jawa Tengah Berdasarkan Indeks Kejahatan Dan Jumlah Pos Keamanan Dengan Metode Klastering K-Means," J. Ilm. SINUS, vol. Vol 14, No, no. ISSN :1693-1173, pp. 59-72, 2016.

[7] D. Gultom, H. D. Tampubolon, L. Y. Hutabarat, F. R. Ilmi H Zer, and D. Hartama, "Penerapan Algoritma K-Means Untuk Mengetahui Tingkat Tindak Kejahatan Daerah Pematangsiantar," J. Teknol. Inf., vol. 4, no. 1, pp. 146-151, 2020 .
[8] S. Handi Kurniawan Sohdianata, "Penerapan Algoritma KMeans Untuk Menetapkan Kelompok Mutu Karet," Progresif, vol. 7, no. 2, pp. 2-9, 2011.

[9] D. Marlina, N. Lina, A. Fernando, and A. Ramadhan, "Implementasi Algoritma K-Medoids dan K-Means untuk Pengelompokkan Wilayah Sebaran Cacat pada Anak," J. CoreIT J. Has. Penelit. Ilmu Komput. dan Teknol. Inf., vol. 4, no. 2, p. 64, 2018, doi: 10.24014/coreit.v4i2.4498.

[10] N. Pulungan, S. Suhada, and D. Suhendro, "Penerapan Algoritma K-Medoids Untuk Mengelompokkan Penduduk 15 Tahun Keatas Menurut Lapangan Pekerjaan Utama," KOMIK (Konferensi Nas. Teknol. Inf. dan Komputer), vol. 3, no. 1, pp. 329-334, 2019, doi: 10.30865/komik.v3i1.1609.

[11] E. Elisa and A. Annurullah, "Data Mining dalam Menganalisis Faktor Alasan Pemilihan Perumahan," no. September, pp. 43$48,2020$. 